\title{
THE EFFECTS OF COPPER-ZINC INTERACTIONS ON YIELD AND YIELD COMPONENTS IN SOILLESS GROWN BEANS (PHASEOLUS VULGARIS L.)
}

\author{
BILLİRİCI, N. \\ Yüzüncü Yıl University, Gevaş Vocational School of Higher Education, Department of Plant \\ and Animal Production, Gevaş, Van, Turkey \\ (e-mail: numanbildirici@gmail.com; phone:+90-539-427-3208) \\ (Received 23 $3^{\text {rd }}$ Jul 2019; accepted $12^{\text {th }}$ Feb 2020)
}

\begin{abstract}
This research was conducted under the ecological conditions of Van-Gevaş, Turkey in 2015 and 2016 in three replications according to the Random Parcel Trial Pattern. This study is a flowerpotting trial investigating the effects of copper $(\mathrm{Cu})$ and zinc $(\mathrm{Zn})$ doses applied in increasing amounts to the bean plant grown in the hydroponic system. Four different copper doses (0-200-400-800 $\left.\mathrm{mg} \mathrm{Cu} \mathrm{kg}^{-1}\right)$ and four different zinc doses (0-2.5-5.0-10.0 $\left.\mathrm{mg} \mathrm{Zn} \mathrm{kg}^{-1}\right)$ were applied. This study was conducted in drybean varieties on different doses and interactions of $\mathrm{Cu}$ and $\mathrm{Zn}$; characteristics such as plant height, number of pods in the plant, number of branches, grain yield in the plant, harvest index and protein ratio were examined. According to the results of the research, while the of $400 \mathrm{mg} \mathrm{kg}^{-1} \mathrm{Cu}$ and $5.0 \mathrm{mg} \mathrm{kg}^{-1} \mathrm{Zn}$ dose applied to Yakutiye-98 variety in the first year increased the seed yield $\left(36.32 \mathrm{~g} \mathrm{plant}^{-1}\right)$ in the plant; in the second year, $200 \mathrm{mg} \mathrm{kg}^{-1} \mathrm{Cu}$ applied to Yakutiye-98 variety and $5.0 \mathrm{mg} \mathrm{kg}^{-1} \mathrm{Zn}$ increased the yield (28.45 $\left.\mathrm{g} \mathrm{plant}^{-1}\right)$. In general copper-zinc interaction; Co-administration of $\mathrm{Cu}$ and $\mathrm{Zn}$ doses led to increases in yield and yield parameters of bean varieties compared to the separate administration of these doses and was found statistically significant at $1 \%$ level.
\end{abstract}

Keywords: dry beans, hydroponics, copper, zinc, fertilizer, grain yield

\section{Introduction}

High content of protein in the composition of grains between $22-30 \%$ is sufficient by carbohydrates; bean is an important legume plant as it is rich in potassium, calcium, magnesium and phosphorus and also has various vitamins. It is in the first place among legumes in terms of cultivation and production in the world. Dry and fresh consumption of bean is very common. Around 29 million hectares of land is cultivated in the world. The total production is 23 million tons and the yield per hectare is $800 \mathrm{~kg}$ (FAO, 2017). In Turkey, bean cultivation area is 848 thousand ha, 220 thousand tons of production and $2590.00 \mathrm{~kg} \mathrm{ha}^{-1}$ yield is obtained (TUiK, 2018).

As the world population increases rapidly, food consumption is increasing accordingly. This brings about an urgent need for increasing the production together with the need for vegetable protein sources. In order to increase production in existing agricultural areas, grain yield per unit area should be increased. For this reason, it is very important to apply the macro and micro nutrients in sufficient doses considering the interactions with each other as well as technical agricultural practices.

Copper $(\mathrm{Cu})$ and zinc $(\mathrm{Zn})$ are absolutely essential micro nutrients for plants. However, although it is necessary for the life of living things, high doses cause toxic effects on plants and other living things. Although high concentrations of $\mathrm{Cu}$ and $\mathrm{Zn}$ is toxic, they are part of molecules that play a key role in photo-synthetic electron transport and enzyme activation (Raven et al., 1999).

Copper is a micro nutrient in plants and it is required for respiration, protein synthesis and chlorophyll production. Indeed, it is very effective in protein and carbohydrate 
metabolism. It is an important trace element due to its role in carbohydrate and lipid metabolism through influencing enzyme activity in plants (Kacar and Katkat, 2006). Activation and electron transfer of many oxidase enzymes are carried out by copper $(\mathrm{Cu})$. In particular, the role of copper in the symbiotic nitrogen fixation in legume plants as the subject to this study is important (McCauley et al., 2009). In addition, $\mathrm{Cu}$ is an effective element in plant resistance against fungal diseases and in controlling plant moisture (Plaster, 1992).

Copper is present in the soil attached to organic materials, manganese (Mn) and iron (Fe) oxides. As a matter of fact, copper deficiency can be seen in soils rich in organic matter and ready pit soils containing more than $50 \%$ organic matter because organic matter holds copper very strongly. In addition, silicates contain copper, which changes and dissolves in weak amounts. Washing of sandy soils also causes copper deficiency. In the absence of copper in the young leaves of plants, chlorosis necrosis such as jaundice is seen, development is stunted, maturation is late and sometimes due to the excess color matter the coffee color symptoms are detected. However, in copper deficiency, plants are particularly vulnerable to fungal diseases caused by fungi. Carbohydrate content in $\mathrm{Cu}$ deficiency is very low in the plant. In addition, it was found that the nodule formation in legume plants was interrupted and a small amount of $\mathrm{N}$ was fixed (McCauley et al., 2009; Bolat and Kara, 2017).

Copper concentration in clean soils that are not polluted in nature varies between 2-40 ppm, while in dirty soils this value can increase up to $1000 \mathrm{ppm}$ (Sönmez et al., 2006a). Toxic effects occur when the amount of copper in the soil is high and it is difficult for plants to take iron up. Therefore, symptoms of chlorosis appear to be iron deficiency. Another disadvantage of the excess copper in plants is the slowdown of root and shoot development. Also, it's excess in the soil affects the uptake of molybdenum negatively (Bolat and Kara, 2017).

If the amount of copper $(\mathrm{Cu})$ in the dry matter weight of the plant is more than $15-30 \mathrm{mg} \mathrm{Cu} \mathrm{kg}^{-1}$ toxic effects occur. Copper toxicity in the plant generally occurs in the root region and causes some degradation of the plant's physiological properties such as protein synthesis, photosynthesis, respiration, ion exchange and cell membrane structure (Sossé et al., 2004).

Heavy metal pollution is generally seen in soils with physical, chemical and biological degradation. Copper pollution is caused by natural disasters such as earthquakes, volcanic eruptions and floods as well as anthropogenic activities such as industrial, urban, mining and pesticide use in agriculture and the use of sewage wastes as fertilizers (Karaca and Turgay, 2012; Dağhan and Öztürk, 2015). It is known that copper fertilizers, copper-containing fungicides and pesticides are used more and more widely than necessary in recent years especially against the fungal factors that are defective in agricultural areas. As a matter of fact, it has been reported that $\mathrm{Cu}$ content is close to the critical toxicity limit in the Mediterranean Region soils of Turkey and $\mathrm{Cu}$ content is above the critical limit in 8\% of greenhouse soils (Kaplan, 1999).

Zinc (Zn) plays a role in the metabolism of certain hormones such as auxin, which provides the formation of shoots, and it is also important for the activity of various enzymes that occur in the plant (Marschner, 1997; Kaya et al., 2018). Zinc is one of the micro nutrients that is essential for plants in small amounts. The effect of zinc in plants is similar to magnesium $(\mathrm{Mg})$ and manganese $(\mathrm{Mn})$. Zinc enzyme activation is directly effective in the formation of product quantity and quality due to its effect on photosynthesis, respiration and biological membrane stability (Rout and Das, 2003). At the same time, zinc which acts on 
nitrogen $(\mathrm{N})$ metabolism in plants, is effect in the formating of starch and ripening of seed (McCauley et al., 2009).

Zinc is present in the soil in the form of oxides in silicate minerals, bonded to clay minerals or in combination with organic matter. While the $\mathrm{Zn}$ concentration in the soil varies between $10-300 \mathrm{ppm}$, it is reported that the $\mathrm{Zn}$ concentration that can be taken by plants varies between 3.6-5.5 ppm (Öktüren Asri and Sönmez, 2006). Zinc toxicity in plants generally occurs above $400 \mathrm{ppm}$. Root and shoot growth of plants exposed to zinc toxicity weakens, roots become thin, young leaves curl and signs of chlorosis appear. In addition, cell growth and elongation are interrupted, cell organelles are broken down and chlorophyll synthesis is reduced (Rout and Das, 2003; Öktüren Asri and Sönmez, 2006). The zinc in the soil occurs in complex compounds that do not dissolve in time. This bonding of zinc ( $\mathrm{Zn})$ also affects the high soil $\mathrm{pH}$. In contrast, the solubility of zinc compounds increases as the soil gains an acidic character. Zinc poisoning due to excess zinc in the soil is a very rare condition in plants. Likewise, the zinc content of plants grown in soils close to mineral deposits can be quite high. When the $\mathrm{Zn}$ concentration is high, the root and leaf growth of the plant is significantly weakened. In addition, the nitrogen, phosphorus and iron uptake rate of the plant decreases (Bolat and Kara, 2017).

Zinc deficiency is generally found in soils with high alkaline $\mathrm{pH}$ and alkaline plants with high basic character (Marschner, 1997; Bolat and Kara, 2017). In Zn deficiency, carbohydrate, protein and auxin metabolism is damaged due to the decrease in enzyme activity. The most obvious symptom of zinc deficiency in plants is a dwarf development and small leaf formation caused by deterioration of auxin metabolism and especially decrease in IAA synthesis (Kacar and Katkat, 2006; Kaya et al., 2018). In addition, chlorose-like necrosis appear between the veins of the leaves. The veins of such leaves may be green, the color of the parts between the veins are yellowish green, yellow or white. Leaf formation in plants decreases, leaves become sparse, top shoots die and early foliage is seen (Plaster, 1992).

It is reported that the amount of tryptophan in zinc deficiency in legume plants is decreased, protein synthesis is stopped and the quality of the product is adversely affected due to the accumulation of free amino acids (Yalçın and Usta, 1990; Toğay and Anlarsal, 2008).

Zinc deficiency not only limits crop yield but also lowers product quality. As a matter of fact, the lack of zinc in agricultural areas is quite common in recent years. Because, $30 \%$ of agricultural land in the world $83 \%$, if in Turkey; It has been determined by studies that it contains less than $0.5 \mathrm{ppm} \mathrm{Zn}$ and it is reported that zinc deficiency is at significant levels in agricultural areas (Yağmur and Aydın, 2013).

In this study, the effect of increasing $\mathrm{Cu}$ and $\mathrm{Zn}$ doses and different dose application interactions on yield and yield characteristics of bean cultivars, a legume plant, was investigated. Bildirici et al. (2016) conducted different researches on the effect of heavy metals on beans in Van and its soils. They determined the relationships between some growth parameters and micro nutrients ( $\mathrm{Zn}, \mathrm{Cu}, \mathrm{Mn}, \mathrm{Mg}, \mathrm{Pb}, \mathrm{Co}, \mathrm{Cd}$ and $\mathrm{Fe}$ ). In line with this information; The aim of this study was to investigate the effects of copper $(\mathrm{Cu})$ and zinc $(\mathrm{Zn})$ nutrients and their interactions on the yield and yield components of bean plants grown hydroponically in the unheated greenhouse of Gevaş Vocational School of Yüzüncü Yil University. 


\section{Materials and Methods}

This research was conducted in Turkey's Van province in 2015 and 2016 in three replications according to the Random Parcel Trial Pattern. The trial was carried out with hydroponic system in the un-heated greenhouse of Yüzüncü Yıl University in Gevaş District of Van. In the experiment, Göynük-98(Ç1) and Yakutiye-98(Ç2) bean varieties registered in 1998 were used as plant material. These varieties are among Turkey's proprietary 12 varieties of beans. It is white and coarse colored and registered to Eastern Anatolia Agricultural Research Institute (Şehirali, 1988).

Cocopeat, which is rich in organic matter, was preferred as soil material in order to see the effects of copper $(\mathrm{Cu})$ and zinc $(\mathrm{Zn})$ doses applied to bean cultivars. Its properties and nutrient content are given in Table 1.

Table 1. Some physical and chemical properties of Cocopeat*

\begin{tabular}{|c|c|}
\hline Soil Properties & Values \\
\hline $\mathrm{pH}$ & $5.5-6.5$ \\
\hline Cation exchange capacity ( meq/100g) & 64-130 \\
\hline Electrical transmission ( EC ) & $0.5-1.0 \mathrm{mS} / \mathrm{cm}$ \\
\hline Compression ratio & $5: 1$ \\
\hline Color & Light brown-dark brown \\
\hline Appearance & Short fiber and granular \\
\hline Fiber & $25 \%$ \\
\hline Fiber length & $3-30 \mathrm{~mm}$ \\
\hline Particle size & $0.1-9 \mathrm{~mm}$ \\
\hline Water holding capacity & 9 times dry weight \\
\hline Total porosity & $96 \%$ \\
\hline \multicolumn{2}{|c|}{ Composition ( $\%$ by dry weight) } \\
\hline Organic matter & $94-98$ \\
\hline Organic carbon & $45-50$ \\
\hline Lignin & $65-70$ \\
\hline Cellulose & $20-30$ \\
\hline $\mathrm{N}$ & 0.30 \\
\hline $\mathrm{K} 2 \mathrm{O}$ & 0.90 \\
\hline $\mathrm{P} 2 \mathrm{O} 5$ & 0.05 \\
\hline $\mathrm{CaO}$ & 0.40 \\
\hline $\mathrm{C}: \mathrm{N}$ rate & $80: 1$ \\
\hline
\end{tabular}

*Gül, 2008

The micro nutrients subject to the study are copper $(\mathrm{Cu})$ and zinc $(\mathrm{Zn}) . \mathrm{CuSO}_{4} \cdot$ $5 \mathrm{H}_{2} \mathrm{O}$ copper sulfate as $\mathrm{Cu}$ source; $\mathrm{ZnSO}_{4} \cdot 7 \mathrm{H}_{2} \mathrm{O}$ zinc sulfate solution was applied homogeneously to the pots before sowing (Eren and Mert, 2016). $\mathrm{Cu}$ and $\mathrm{Zn}$ doses applied in the experiment were determined by taking into consideration the averages and upper limits reported by Lindsay (1978).

The research was established with randomized plot design with 3 replications. Before sowing the pots; 4 different levels of copper dose $\left[0 \mathrm{mg} \mathrm{kg}^{-1}(\mathrm{Cu} 1), 200 \mathrm{mg} \mathrm{kg}^{-1}(\mathrm{Cu} 2)\right.$, $\left.400 \mathrm{mg} \mathrm{kg}^{-1}(\mathrm{Cu} 3), 800 \mathrm{mg} \mathrm{kg}^{-1}(\mathrm{Cu} 4)\right]$ in copper sulfate $\left(\mathrm{CuSO}_{4} \cdot 5 \mathrm{H}_{2} \mathrm{O}\right)$ format and 4 different levels of zinc dose $\left[0 \mathrm{mg} \mathrm{kg}^{-1}(\mathrm{Zn} 1), 2.5 \mathrm{mg} \mathrm{kg}^{-1}(\mathrm{Zn} 2), 5.0 \mathrm{mg} \mathrm{kg}^{-1}(\mathrm{Zn} 3)\right.$, $\left.10.0 \mathrm{mg} \mathrm{kg}^{-1}(\mathrm{Zn} 4)\right]$ in zinc sulfate $\left(\mathrm{ZnSO}_{4} \cdot 7 \mathrm{H}_{2} \mathrm{O}\right)$ were determined. The main reason for the high application of copper doses is the widespread use of $\mathrm{Cu}$-containing pesticides, especially in agricultural pesticides. In addition to this, to observe the possible effects of copper toxicity and the effects of copper-zinc interactions on beans 
due to the increase in the use of sewage residues such as sewage sludge as fertilizer in plant production. The experiment subjects consisted of 2 bean varieties and 4 different application doses for each element.

In this study, $540 \mathrm{~g}$ of cocopeat was placed in 3 liter pots with a diameter of $16.5 \mathrm{~cm}$ and a depth of $19.0 \mathrm{~cm}$. In the experiment, seed sowing process was made 1 week after the copper application for the incubation of the copper given to the pots. Bean varieties seeds were sowed in the first year on 07.05.2015 and the second year on 10.05.2016 with one plant per flowerpot. Irrigation and fertilization of the test pots were carried out evenly and homogeneously after the exit. In the research, the macro and micro basic nutrients required by the plant were prepared as separate solutions (Buttaro et al., 2012; Di Lorenzo et al., 2013). In the preparation of the nutrient solution, Tangolar et al.'s work (2017) on the soilless culture system was used. The applied nutrient solution mixture was prepared in $150 \mathrm{ppm}$ nitrogen $(\mathrm{N})$ as $\mathrm{NH}_{4} \mathrm{NO}_{3} ; 20 \mathrm{ppm}$ phosphorus $(\mathrm{P})$ as $\mathrm{H}_{3} \mathrm{PO}_{4} ; 100$ ppm potassium $(\mathrm{K})$ as $\mathrm{K}_{2} \mathrm{SO}_{4} ; 15$ ppm magnesium $(\mathrm{Mg})$ as $\mathrm{MgSO}_{4} ; 10 \mathrm{ppm}$ sulfur (S) sulphate in the form of compounds; 5 ppm iron (Fe) as Fe-EDDHA; 3 ppm manganese $(\mathrm{Mn})$ as $\mathrm{MnSO}_{4}$ format; It was formed of three different solutions in 0.4 ppm boron (B) as $\mathrm{H}_{3} \mathrm{BO}_{3}$ and $0.05 \mathrm{ppm}$ molybdenum (Mo) as $\mathrm{NH}_{4} \mathrm{Mo}_{7} \mathrm{O}_{24} 4 \mathrm{H}_{2} \mathrm{O}$. The plants were periodically fertilized once a week by introducing these three nutrient mixtures into the system. In both years of the study, the application of nutrient solution was started when the plants had 4-5 leaves and $1.0 \mathrm{~mL}$ of plant ${ }^{-1}$ from macro nutrient solution and $0.5 \mathrm{~mL}$ of plant ${ }^{-1}$ from micro nutrient solution were applied. The $\mathrm{pH}$ value of the deionized water used in this study was determined as 7.45 and electrical conductivity as 0.667 .

In the experiment, harvesting was carried out on 4 October in 2015 and on 22 September in 2016 based on the physiological yellow maturity of the beans. The plants were harvested after 120-130 days of ripening period and the following characteristics were examined in comparison of the applications;

Plant height $(\mathrm{cm})$, number of pods (number of plant ${ }^{-1}$ ), number of branches (number of plant $\left.{ }^{-1}\right)$, grain yield in the plant $\left(\mathrm{g} \mathrm{plant}^{-1}\right)$, harvest index $(\%)$ and protein content $(\%)$ characteristics were measured (Yağmur and Aydın, 2013; Tangolar et al., 2017).

In the study, randomized experiment design variance analysis method was used in statistical evaluation of the effects of different doses of $\mathrm{Cu}$ and $\mathrm{Zn}$ applications on yield and yield components of plant and interactions of nutrient concentrations. In determining different groups; Duncan's (5\%) Multiple Comparison Test (Düzgüneş et al., 1987), Costat and Mstatc package programs were used.

\section{Results}

\section{Plant height (cm)}

According to the data obtained at the end of the research, in year 2015, varieties, copper $(\mathrm{Cu})$ doses and varieties x copper $(\mathrm{Cu})$ interactions were significant; zinc $(\mathrm{Zn})$, cultivar $\mathrm{x}$ zinc $(\mathrm{Zn})$, copper $\mathrm{x}$ zinc and $\mathrm{C} \times \mathrm{xu} \times \mathrm{Zn}$ interactions were statistically insignificant. In 2016, except for cultivar $x$ copper $(\mathrm{Cu})$ and Cultivar $x \mathrm{Cu} \times \mathrm{Zn}$ interactions, other differences between plant averages were significant (Table 2).

As shown in Table 2, the average plant height in 2015 and 2016 was obtained as higher in Göynük-98 (Ç1) cultivar (with 50.82-44.86 cm), compared to Yakutiye-98 (Ç2) cultivar. The average plant height values obtained from different copper doses in the experiment varied between $53.08-45.14 \mathrm{~cm}$ in 2015 and $46.19-41.39 \mathrm{~cm}$ in 2016. 
Table 2. Bean varieties in the groups and averages related to the height of the plant $(\mathrm{cm})^{*}$

\begin{tabular}{|c|c|c|c|c|c|c|c|c|c|c|c|c|c|}
\hline \multirow{3}{*}{\multicolumn{2}{|c|}{\begin{tabular}{lc} 
& \\
\cline { 3 - 3 } Variety & $\begin{array}{c}\mathrm{Cu} \\
\text { Doses }\end{array}$ \\
\end{tabular}}} & \multirow{2}{*}{\multicolumn{6}{|c|}{$\frac{2015}{\text { Zn Doses }}$}} & \multirow{2}{*}{\multicolumn{6}{|c|}{$\begin{array}{c}2016 \\
\text { Zn Doses }\end{array}$}} \\
\hline & & & & & & & & & & & & & \\
\hline & & Zn1 & Zn2 & Zn3 & Zn4 & $\begin{array}{c}\text { Ç x Cu. } \\
\text { Ave. }\end{array}$ & $\begin{array}{c}\text { Ç. } \\
\text { Ave. }\end{array}$ & Zn1 & Zn2 & Zn3 & Zn4 & $\begin{array}{c}\text { Ç x Cu. } \\
\text { Ave. }\end{array}$ & $\begin{array}{c}\text { Ç. } \\
\text { Ave. }\end{array}$ \\
\hline \multirow{4}{*}{ Ç1 } & Cu1 & 47.64 & 44.60 & 49.02 & 50.44 & $47.92 \mathrm{ABC}$ & & 44.14 & 41.43 & 41.19 & 38.80 & 41.39 & \\
\hline & $\mathrm{Cu} 2$ & 52.00 & 51.58 & 54.49 & 52.18 & $52.56 \mathrm{AB}$ & & 46.62 & 45.07 & 50.74 & 40.97 & 45.85 & \\
\hline & $\mathrm{Cu3}$ & 52.50 & 55.10 & 51.87 & 52.83 & $53.08 \mathrm{~A}$ & 50.82 & 46.95 & 42.75 & 50.97 & 44.09 & 46.19 & $44.86 \mathrm{~A}$ \\
\hline & $\mathrm{Cu} 4$ & 48.14 & 49.16 & 53.71 & 47.90 & 49.73ABC & & 46.90 & 43.48 & 51.15 & 42.54 & 46.02 & \\
\hline \multicolumn{2}{|c|}{ ÇxZn Ave. } & 50.07 & 50.11 & 52.27 & 50.84 & & & 46.15B & \multicolumn{5}{|c|}{ 43.18C 48.51A 41.60D } \\
\hline & $\begin{array}{c}\mathrm{Cu} \\
\text { Doses }\end{array}$ & Zn1 & Zn2 & Zn3 & Zn4 & $\begin{array}{c}\text { Ç x Cu. } \\
\text { Ave. }\end{array}$ & $\begin{array}{c}\text { Ç. } \\
\text { Ave. }\end{array}$ & Zn1 & Zn2 & Zn3 & Zn4 & $\begin{array}{c}\text { Ç x Cu. } \\
\text { Ave. }\end{array}$ & $\begin{array}{c}\text { Ç. } \\
\text { Ave. }\end{array}$ \\
\hline \multirow{4}{*}{ Ç2 } & Cu1 & 45.42 & 42.81 & 46.64 & 47.50 & $45.59 \mathrm{C}$ & \multirow{4}{*}{45.80} & 45.24 & 44.85 & 42.54 & 43.96 & 44.15 & \multirow{4}{*}{$44.63 \mathrm{~B}$} \\
\hline & $\mathrm{Cu} 2$ & 47.57 & 45.66 & 44.36 & 47.54 & 46.28BC & & 44.23 & 46.52 & 45.21 & 45.07 & 45.26 & \\
\hline & $\mathrm{Cu3}$ & 45.14 & 48.13 & 46.82 & 44.78 & $46.22 \mathrm{BC}$ & & 42.89 & 47.11 & 46.27 & 46.80 & 45.77 & \\
\hline & $\mathrm{Cu} 4$ & 45.01 & 45.78 & 45.57 & 44.19 & $45.14 \mathrm{C}$ & & 40.78 & 45.78 & 40.35 & 46.41 & 43.34 & \\
\hline \multicolumn{2}{|c|}{ ÇxZn Ave. } & 45.79 & 45.60 & 45.85 & 46.00 & & & $43.29 \mathrm{~B}$ & $46.07 \mathrm{~A}$ & 43.59B & $45.56 \mathrm{~A}$ & & \\
\hline \multicolumn{2}{|c|}{$\begin{array}{l}\text { Zn Ave. } \\
\text { Yll Ave. }\end{array}$} & 47.93 & 47.85 & $\begin{array}{r}49.06 \\
48\end{array}$ & $\begin{array}{l}48.42 \\
.31 \mathrm{~A}\end{array}$ & & & \multicolumn{5}{|c|}{$45.41 \mathrm{~B}$} & \\
\hline & & Zn1 & Zn2 & Zn3 & Zn4 & Cu Ave. & & Zn1 & $\operatorname{Zn} 2$ & Zn3 & Zn4 & $\begin{array}{c}\mathrm{Cu} \\
\text { Ave.. }\end{array}$ & \\
\hline \multirow{4}{*}{$\mathrm{Cu} \times \mathrm{Zn}$} & Cu1 & 45.42 & 42.81 & 46.64 & 47.50 & $46.75 \mathrm{~B}$ & & $44.69 b c$ & $43.14 \mathrm{c}$ & $41.87 \mathrm{~d}$ & $41.38 \mathrm{~d}$ & $42.77 \mathrm{~B}$ & \\
\hline & $\mathrm{Cu} 2$ & 47.57 & 45.66 & 44.36 & 47.54 & $49.42 \mathrm{~A}$ & & $45.43 b$ & $45.80 \mathrm{~b}$ & $47.98 \mathrm{ab}$ & $43.02 \mathrm{c}$ & $45.55 \mathrm{~A}$ & \\
\hline & $\mathrm{Cu3}$ & 45.14 & 48.13 & 46.82 & 44.78 & $49.65 \mathrm{~A}$ & & $44.92 \mathrm{bc}$ & $44.93 b c$ & $48.62 \mathrm{a}$ & $45.45 b$ & $45.98 \mathrm{~A}$ & \\
\hline & $\mathrm{Cu} 4$ & 45.01 & 45.78 & 45.57 & 44.19 & 47.43B & & $43.84 \mathrm{c}$ & $44.63 \mathrm{bc}$ & $45.75 b$ & $44.48 b \mathrm{bc}$ & c $44.67 \mathrm{~A}$ & \\
\hline LSD $_{0.05}$ & \multicolumn{7}{|c|}{$\begin{array}{c}1.51 \\
\end{array}$} & \multicolumn{6}{|c|}{1.24} \\
\hline \multicolumn{2}{|l|}{ C.V (\%) } & \multicolumn{6}{|c|}{5.43} & \multicolumn{6}{|c|}{4.72} \\
\hline
\end{tabular}

*The difference between the averages indicated by the same letters is not significant at $5 \%$ level. $\mathrm{Cu}$ : Copper Dose, Zn: Zinc Dose, Ç1: Göynük-98, Ç2: Yakutiye-98, Avg.: Average, ÇxCu: Variety x Copper Dose Interaction, Ç x Zn: Variety x Zinc Dose Interaction, $\mathrm{Cu}$ x Zn: Copper x Zinc Dose Interaction

According to the results of the research, the plant height in the averages of in 2015 and 2016 and both year averages was obtained from the applications of $400 \mathrm{mg} \mathrm{kg}^{-1}$ Cu3 applied, respectively to Göynük-98 variety with $53.08-46.19 \mathrm{~cm}$.

In the first year of the experiment, the lowest plant height was determined as 45.14 $\mathrm{cm}$ with $800 \mathrm{mg} \mathrm{kg}^{-1} \mathrm{Cu} 4$ dose applied to Yakutiye-98 cultivar. In the second year, the low plant height was $41.39 \mathrm{~cm}$ and it was obtained from Göynük-98 variety without copper application.

It was determined that the plant height value was higher in plots with $5.0 \mathrm{mg} \mathrm{kg}^{-1}$ zinc dose applied to Göynük-98 cultivar $(52.27-48.51 \mathrm{~cm})$ in both years of the experiment. The shortest plant length was measured in Yakutiye-98 cultivar, where a dosage of $41.60 \mathrm{~cm}$ and $2.5 \mathrm{mg} \mathrm{kg}^{-1}$ zinc was applied. In similar studies on legumes, they reported that increased zinc fertilization increased plant height (Togay and Anlarsal, 2008).

In terms of zinc $x$ copper doses applied in the study, the interaction effect between the doses in 2015 was found to be statistically insignificant. In 2016, the effect of the interaction between $5.0 \mathrm{mg} \mathrm{kg}^{-1}$ zinc dose and $800 \mathrm{mg} \mathrm{kg}^{-1}$ copper doses applied to Göynük-98 bean variety was found to be statistically significant in terms of plant height $(51.15 \mathrm{~cm})$ (Table 2).

It is known in the studies on legumes that increasing doses of zinc fertilization increases the plant height to a certain extent. However, this difference between years is 
thought to be due to the effect of climate factors as well as the usefulness of copper applied. As a matter of fact, the expected benefit from fertilizing in terms of yield and quality in crop production depends on the application of the right fertilizer source at the right time, with the right methods and appropriate quantities.

\section{Number of pods (pieces / plant)}

According to the results of the experiment, there was a difference between the number of pods between the years. On average number of pods in 2015 copper and zinc doses, varieties $\mathrm{x}$ copper and varieties $\mathrm{x}$ zinc dose interactions were significant, varieties, copper $\mathrm{x}$ zinc and varieties $\mathrm{x}$ copper $\mathrm{x}$ zinc interactions were statistically insignificant. In 2016, varieties, copper, zinc, copper x zinc interactions were found to be statistically significant.

The average number of pods obtained as a result of the research was counted as 14.12 in the first year and 9.31 in the second year. According to the results obtained, the average number of pods in years for Göynük-98 variety, was respectively, 14.04-9.93 in the other varieties of Yakutiye-98 variety was determined as 14.20-8.71 (Table 3).

Table 3. Averages and formed groups on number of pods in bean varieties (pieces / plant)*

\begin{tabular}{|c|c|c|c|c|c|c|c|c|c|c|c|c|}
\hline & \multicolumn{5}{|c|}{2015} & \multicolumn{6}{|c|}{2016} \\
\hline & & \multicolumn{5}{|c|}{ Zn Doses } & \multicolumn{6}{|c|}{ Zn Doses } \\
\hline Variety & $\begin{array}{c}\mathrm{Cu} \\
\text { Doses }\end{array}$ & Zn1 & Zn2 & Zn3 & Zn4 & $\begin{array}{c}\text { Ç x Cu. Ç. } \\
\text { Ave. Ave. }\end{array}$ & Zn1 & $\operatorname{Zn} 2$ & Zn3 & Zn4 & $\begin{array}{l}\text { Ç x Cu. } \\
\text { Ave. }\end{array}$ & $\begin{array}{l}\text { Ç. } \\
\text { Ave. }\end{array}$ \\
\hline \multirow{4}{*}{ Ç1 } & Cu1 & 10.46 & 12.66 & 15.61 & 13.88 & $13.15 \mathrm{AB}$ & 8.08 & 9.18 & 8.81 & 8.96 & 8.76 & \\
\hline & $\mathrm{Cu} 2$ & 12.53 & 15.21 & 14.71 & 15.15 & $14.40 \mathrm{AB}$ & 8.81 & 9.73 & 10.03 & 12.55 & 10.28 & \\
\hline & $\mathrm{Cu} 3$ & 13.18 & 13.34 & 15.35 & 15.48 & $14.34 \mathrm{AB} \quad 14.04$ & 10.01 & 10.34 & 11.62 & 10.27 & 10.55 & $9.93 \mathrm{~A}$ \\
\hline & $\mathrm{Cu} 4$ & 14.04 & 12.00 & 15.55 & 15.45 & $14.26 \mathrm{AB}$ & 10.28 & 11.30 & 10.02 & 8.80 & 10.10 & \\
\hline \multicolumn{2}{|c|}{ ÇxZn Ave. } & \multicolumn{5}{|c|}{ 12.55D 13.30C 15.31A 14.99B } & \multicolumn{6}{|c|}{$9.30 \mathrm{~B} \quad 10.13 \mathrm{~A} \quad 10.12 \mathrm{~A} 10.15 \mathrm{~A}$} \\
\hline & $\begin{array}{c}\mathrm{Cu} \\
\text { Doses }\end{array}$ & Zn1 & Zn2 & Zn3 & Zn4 & $\begin{array}{cc}\text { Ç x Cu. } & \text { Ç. } \\
\text { Ave. } & \text { Ave. }\end{array}$ & Zn1 & Zn2 & $\mathrm{Zn3}$ & Zn4 & $\begin{array}{c}\text { Ç x Cu. } \\
\text { Ave. }\end{array}$ & $\begin{array}{c}\text { Ç. } \\
\text { Ave. }\end{array}$ \\
\hline \multirow{4}{*}{ Ç2 } & Cu1 & 11.80 & 12.67 & 14.24 & 11.57 & $12.57 \mathrm{~B}$ & 7.77 & 8.25 & 7.96 & 7.05 & 7.76 & \multirow{4}{*}{$8.71 \mathrm{~B}$} \\
\hline & $\mathrm{Cu} 2$ & 14.76 & 12.12 & 15.25 & 16.57 & $14.68 \mathrm{AB}$ & 9.12 & 8.79 & 10.07 & 10.12 & 9.52 & \\
\hline & $\mathrm{Cu3}$ & 16.58 & 14.78 & 17.37 & 16.47 & $16.30 \mathrm{~A} \quad 14.20$ & 8.29 & 10.95 & 9.28 & 7.71 & 9.06 & \\
\hline & $\mathrm{Cu} 4$ & 13.91 & 11.96 & 13.79 & 13.34 & $13.25 \mathrm{AB}$ & 7.74 & 9.88 & 8.39 & 7.93 & 8.48 & \\
\hline \multicolumn{2}{|c|}{ ÇxZn Ave. } & \multicolumn{5}{|c|}{ 14.26B 12.88C 15.16A 14.49B } & \multicolumn{6}{|c|}{$9.47 \mathrm{~A} 8.93 \mathrm{AB} 8.19 \mathrm{~B}$} \\
\hline \multirow{2}{*}{\multicolumn{2}{|c|}{$\begin{array}{l}\text { Zn Ave. } \\
\text { Yll Ave. }\end{array}$}} & \multicolumn{5}{|c|}{$\begin{array}{c}13.41 \mathrm{~B} 13.09 \mathrm{~B} 15.23 \mathrm{~A} 14.74 \mathrm{~A} \\
14.12 \mathrm{~A}\end{array}$} & \multicolumn{6}{|c|}{$\begin{array}{c}9.80 \mathrm{~A} 9.52 \mathrm{AB} 9.17 \mathrm{~B} \\
9.31 \mathrm{~B}\end{array}$} \\
\hline & & Zn1 & Zn2 & Zn3 & Zn4 & Cu Ave. & Zn1 & Zn2 & Zn3 & Zn4 & Cu Ave. & \\
\hline \multirow{4}{*}{$\mathrm{Cu} \times \mathrm{Zn}$} & Cu1 & 11.13 & 12.67 & 14.93 & 12.73 & $12.86 \mathrm{D}$ & $7.93 \mathrm{~d}$ & $8.72 \mathrm{~cd}$ & $8.39 \mathrm{~cd}$ & $8.01 \mathrm{~d}$ & $8.26 \mathrm{~B}$ & \\
\hline & $\mathrm{Cu} 2$ & 13.65 & 13.67 & 14.98 & 15.86 & 14.54B & $8.97 \mathrm{~cd}$ & $9.26 \mathrm{bc}$ & $10.05 b$ & $11.34 \mathrm{a}$ & $9.91 \mathrm{~A}$ & \\
\hline & $\mathrm{Cu3}$ & 14.88 & 14.06 & 16.36 & 15.98 & $15.32 \mathrm{~A}$ & $9.15 b c$ & $10.63 \mathrm{ab}$ & $10.45 \mathrm{ab}$ & $8.99 \mathrm{c}$ & $9.80 \mathrm{~A}$ & \\
\hline & $\mathrm{Cu} 4$ & 13.98 & 11.98 & 14.67 & 14.40 & $13.76 \mathrm{C}$ & $9.01 \mathrm{c}$ & $10.59 \mathrm{ab}$ & $9.21 b c$ & $8.35 \mathrm{~cd}$ & $9.29 \mathrm{~A}$ & \\
\hline \multicolumn{2}{|l|}{ LSD 0.05} & \multicolumn{5}{|c|}{0.80} & \multicolumn{6}{|c|}{0.73} \\
\hline C.V (\%) & & \multicolumn{5}{|c|}{9.88} & \multicolumn{6}{|c|}{13.64} \\
\hline
\end{tabular}

*The difference between the averages indicated by the same letters is not significant at $5 \%$ level. $\mathrm{Cu}$ : Copper Dose, Zn: Zinc Dose, Ç1: Göynük-98, Ç2: Yakutiye-98, Avg.: Average, ÇxCu: Variety x Copper Dose Interaction, Ç x Zn: Variety x Zinc Dose Interaction, $\mathrm{Cu}$ x Zn: Copper x Zinc Dose Interaction

According to the data obtained, the interaction of varieties $\mathrm{x}$ copper doses in the first year was statistically significant and the second year was insignificant on the average 
number of pods. The highest number of broad beans was obtained from Yakutiye-98 bean cultivars with 16.30 doses of $400 \mathrm{mg} \mathrm{kg}^{-1} \mathrm{Cu} 3$, and the lowest value was obtained from $0 \mathrm{mg} \mathrm{Cu} \mathrm{kg}{ }^{-1} \mathrm{Cu} 1$ control dose in Yakutiye-98 cultivars with 12.57 units. According to these results, increasing doses of copper increased the number of pods per plant up to a certain point and then decreased.

In the study, the interaction of copper $\mathrm{x}$ zinc doses on the average number of pods was found statistically insignificant in the first year and significant in the second year. The highest number of pods was obtained in the first year with 16.36 units of $400 \mathrm{mg} \mathrm{Cu} \mathrm{kg}^{-1}$ $\mathrm{Cu} 3$ and $5.0 \mathrm{mg} \mathrm{Zn} \mathrm{kg} \mathrm{Zn}^{-1} \mathrm{Zn}$. The lowest value was obtained from 0 doses of both application doses with 11.13 units (Table 3). In the second year of the experiment, the highest number of pods was obtained from 11.34 units of $200 \mathrm{mg} \mathrm{Cu} \mathrm{kg}^{-1} \mathrm{Cu} 2$ and $10.0 \mathrm{mg}$ $\mathrm{Zn} \mathrm{kg}^{-1} \mathrm{Zn} 4$. The lowest value was determined in doses of 7.93 with 0 (Table 3). According to these results, increased zinc doses at low copper doses increased the number of pods per plant. It is known that where copper and zinc fertilizer are used together, copper $\mathrm{x}$ zinc decreases the efficiency of use and causes decrease in yield and quality.

\section{Number of branches (pieces / plant)}

In 2015, it was found that the number of branches, beans, zinc doses, varieties x zinc doses and copper $\mathrm{x}$ zinc doses interactions on the average number of branches were statistically significant. In the second year of the experiment, the effect of all application doses and interactions on the average number of branches in bean cultivars was found to be statistically insignificant (Table 4).

Table 4. Groups and averages of the number of branches in bean varieties (pieces / plant)*

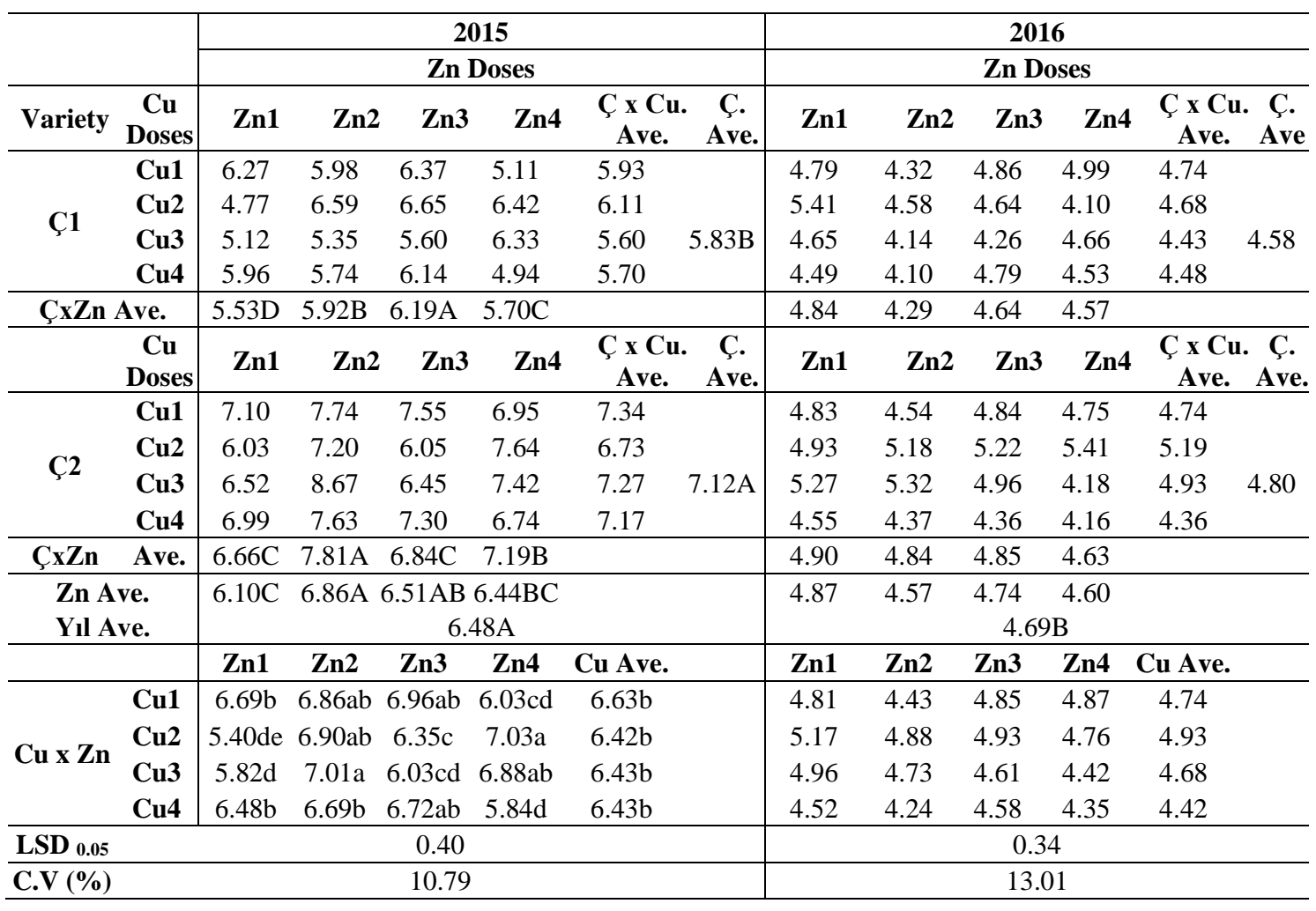

*The difference between the averages indicated by the same letters is not significant at $5 \%$ level. Cu: Copper Dose, Zn: Zinc Dose, Ç1: Göynük-98, Ç2: Yakutiye-98, Avg.: Average, ÇxCu: Variety x Copper Dose Interaction, Ç x Zn: Variety x Zinc Dose Interaction, $\mathrm{Cu}$ x Zn: Copper x Zinc Dose Interaction 
According to the results obtained in the experiment, the average number of branches was 6.48 in the first year and 4.69 in the second year. The number of branches among the bean varieties was obtained from 5.83-4.58 plant $^{-1}$ and Göynük-98 varieties, respectively. In the Yakutiye-98 variety, a higher number (7.12-4.80) of branching was detected (Table 4). According to the results obtained on the average number of branches in the first year $\mathrm{C} \times \mathrm{Zn}$ interaction was statistically significant, the second year was found to be insignificant. According to the results obtained from the experiment, the highest average branch number was obtained from $2.5 \mathrm{mg} \mathrm{kg}^{-1} \mathrm{Zn} 2$ dose applied to Yakutiye-98 cultivar. The lowest value was obtained from the control ( 0 dose) application of Göynük-98 variety with 5.53 units (Table 4).

As shown in Table 4, the effect of $\mathrm{Cu} \times \mathrm{Zn}$ interaction on the mean number of branches was significant $(p<0.01)$. The highest average number of branches was obtained from 7.03 $\mathrm{Zn} 4$ dose of $200 \mathrm{mg} \mathrm{kg}^{-1} \mathrm{Cu} 2 \times 10.0 \mathrm{mg} \mathrm{kg}^{-1}$. The lowest value was measured with 5.40 units of $200 \mathrm{mg} \mathrm{kg}^{-1} \mathrm{Cu} 2 \times 0 \mathrm{mg} \mathrm{kg}^{-1} \mathrm{Zn} 1$ control dose.

\section{Harvest index (\%)}

It was determined that the factors other than cultivars, copper doses, varieties $\mathrm{x}$ copper dose interactions were insignificant on the harvest index of bean cultivars in 2015.

In 2016, the effect of varieties, copper and zinc doses, cultivar $\mathrm{x}$ zinc and $\mathrm{C} \times \mathrm{x} \mathrm{Cu} \times \mathrm{Zn}$ interactions on harvest index averages were found to be statistically significant (Table 5).

Table 5. Groups and averages of harvest index in bean varieties(\%)*

\begin{tabular}{|c|c|c|c|c|c|c|c|c|c|c|c|}
\hline \multirow{3}{*}{ Variety } & \multirow[b]{3}{*}{$\begin{array}{c}\mathrm{Cu} \\
\text { Doses }\end{array}$} & \multicolumn{5}{|c|}{2015} & \multicolumn{5}{|c|}{2016} \\
\hline & & \multicolumn{5}{|c|}{ Zn Doses } & \multicolumn{5}{|c|}{ Zn Doses } \\
\hline & & Zn1 & $\operatorname{Zn} 2$ & Zn3 & Zn4 & $\begin{array}{cc}\text { Çx Cu } & \text { Ç. } \\
\text { Ave. } & \text { Ave. } \\
\end{array}$ & Zn1 & Zn2 & Zn3 & Zn4 & $\begin{array}{cc}\text { Ç x Cu } & \text { Ç. } \\
\text { Ave. } & \text { Ave. } \\
\end{array}$ \\
\hline \multirow{4}{*}{ Ç1 } & Cu1 & 34.51 & 37.12 & 39.39 & 36.18 & $36.80 \mathrm{C}$ & $37.51 \mathrm{~cd}$ & $37.90 \mathrm{c} 3$ & $38.22 \mathrm{c} ?$ & $39.40 \mathrm{bc}$ & 38.26 \\
\hline & $\mathrm{Cu} 2$ & 40.65 & 39.54 & 40.54 & 43.40 & $41.03 \mathrm{~A}$ & $38.52 \mathrm{c}$ & $42.49 \mathrm{a} 4$ & $41.90 \mathrm{ab}$ & $40.66 \mathrm{~b}$ & 40.89 \\
\hline & $\mathrm{Cu} 3$ & 40.28 & 41.69 & 40.56 & 40.70 & 40.81B $38.83 B$ & $39.76 b c$ & $41.26 \mathrm{ab} 3$ & $39.66 b c 3$ & $39.07 b c$ & $39.38 \mathrm{~B}$ \\
\hline & $\mathrm{Cu} 4$ & 39.21 & 35.60 & 37.27 & 34.59 & $36.67 \mathrm{C}$ & $34.85 \mathrm{e}$ & $40.58 \mathrm{~b} 4$ & $41.64 \mathrm{ab}$ & $36.61 \mathrm{~d}$ & 38.42 \\
\hline \multicolumn{2}{|c|}{ ÇxZn Ave. } & 38.66 & 38.49 & 39.44 & 38.72 & & $37.66 \mathrm{C}$ & $40.56 \mathrm{~A} 4$ & $40.36 \mathrm{~A} 3$ & $38.94 \mathrm{~B}$ & \\
\hline & $\begin{array}{c}\mathrm{Cu} \\
\text { Doses }\end{array}$ & Zn1 & $\mathrm{Zn2}$ & $\mathrm{Zn3}$ & Zn4 & $\begin{array}{|cc|}\text { Ç x Cu. } & \text { Ç. } \\
\text { Ave. } & \text { Ave. } \\
\end{array}$ & Zn1 & Zn2 & Zn3 & Zn4 & $\begin{array}{c}\text { Ç x Cu. Ç. } \\
\text { Ave. Ave. }\end{array}$ \\
\hline \multirow{4}{*}{ Ç2 } & Cu1 & 44.25 & 42.44 & 43.68 & 42.04 & 43.10C & $41.73 \mathrm{~cd}$ & $44.37 \mathrm{~b}$ & 43.18 & $42.79 \mathrm{c}$ & 43.02 \\
\hline & $\mathrm{Cu} 2$ & 48.03 & 40.92 & 45.44 & 45.21 & $44.90 \mathrm{~A}$ & $45.20 \mathrm{ab}$ & $44.08 \mathrm{~b}$ & $44.57 \mathrm{~b} 4$ & $45.99 \mathrm{ab}$ & 44.96 \\
\hline & $\mathrm{Cu} 3$ & 44.72 & 42.43 & 45.39 & 43.34 & $43.97 \mathrm{~B} \quad 44.03 \mathrm{~A}$ & $45.51 \mathrm{ab}$ & $43.46 \mathrm{bc}$ & $46.56 \mathrm{a}$ & $46.52 \mathrm{a}$ & $44.07 \mathrm{~A}$ \\
\hline & $\mathrm{Cu} 4$ & 43.24 & 46.42 & 47.05 & 39.94 & $44.16 \mathrm{AB}$ & $43.30 \mathrm{bc}$ & $42.60 \mathrm{c} 4$ & $41.97 \mathrm{~cd} 4$ & $43.30 \mathrm{bc}$ & 42.79 \\
\hline \multicolumn{2}{|c|}{$\begin{array}{l}\text { ÇxZn } \\
\text { Ave. }\end{array}$} & 45.06 & 43.05 & 45.39 & 42.63 & & 43.94B & 43.63B 4 & $44.07 \mathrm{~A}$ & $44.65 \mathrm{~A}$ & \\
\hline \multirow{2}{*}{\multicolumn{2}{|c|}{$\begin{array}{l}\text { Zn Ave. } \\
\text { Yll Ave. }\end{array}$}} & 41.86 & 40.77 & $\begin{array}{r}42.42 \\
41\end{array}$ & $\begin{array}{l}40.68 \\
43 \mathrm{~A}\end{array}$ & & 40.80B & $42.09 \mathrm{~A} 4$ & $\begin{array}{r}42.21 \mathrm{~A} 4 \\
41.72 \\
\end{array}$ & $\begin{array}{l}11.79 \mathrm{AB} \\
2 \mathrm{~B}\end{array}$ & \\
\hline & & Zn1 & Zn2 & $\mathrm{Zn3}$ & Zn4 & Cu Ave. & Zn1 & Zn2 & Zn3 & Zn4 & $\begin{array}{c}\text { Cu } \\
\text { Ave. }\end{array}$ \\
\hline \multirow{4}{*}{$\mathrm{Cu} \times \mathbf{Z n}$} & Cu1 & 39.38 & 39.78 & 41.54 & 39.11 & $39.95 \mathrm{~B}$ & 39.62 & 41.14 & 40.70 & 41.10 & 40.64B \\
\hline & $\mathrm{Cu} 2$ & 44.34 & 40.23 & 42.99 & 44.31 & $42.97 \mathrm{~A}$ & 41.86 & 43.29 & 43.24 & 43.33 & $42.93 \mathrm{~A}$ \\
\hline & $\mathrm{Cu3}$ & 42.50 & 42.06 & 42.98 & 42.02 & $42.39 \mathrm{~A}$ & 42.64 & 42.36 & 43.11 & 42.80 & $42.73 \mathrm{~A}$ \\
\hline & $\mathrm{Cu} 4$ & 41.23 & 41.01 & 42.16 & 37.27 & $40.42 \mathrm{~B}$ & 39.08 & 41.59 & 41.81 & 39.96 & $40.61 \mathrm{~B}$ \\
\hline LSD $_{0.05}$ & \multicolumn{6}{|c|}{1.53} & \multicolumn{5}{|c|}{1.02} \\
\hline C.V (\%) & & \multicolumn{5}{|c|}{6.42} & \multicolumn{5}{|c|}{4.26} \\
\hline
\end{tabular}

*The difference between the averages indicated by the same letters is not significant at $5 \%$ level. $\mathrm{Cu}$ : Copper Dose, Zn: Zinc Dose, Ç1: Göynük-98, Ç2: Yakutiye-98, Avg.: Average, ÇxCu: Variety x Copper Dose Interaction, Ç x Zn: Variety x Zinc Dose Interaction, $\mathrm{Cu}$ x Zn: Copper x Zinc Dose Interaction 
According to the results obtained at the end of the research, harvest index was found to be $38.83-39.38 \%$ in Ç1 (Göynük-98) and 44.03-44.07\% in Ç2 (Yakutiye-98). In this research, the highest harvest index average was obtained from Ç2 according to the results of both years. It is thought that this difference, which occurred a little between the years, is due to environmental factors, genotype and cultural practices.

In the study, average harvest index values obtained from different copper doses applications varied between 42.97-39.95\% in 2015 and 42.93-40.6\% in 2016 (Table 5). According to the results of the study, the highest harvest index in 2015 and 2016 and the average of both years was obtained from $200 \mathrm{mg} \mathrm{kg}^{-1} \mathrm{Cu} 2$ dose applied to Ç2 (Yakutiye-98) with 44.90-45.51\%, respectively. In the first year of the experiment, the lowest harvest index value was found to be $800 \mathrm{mg} \mathrm{Cu} \mathrm{kg}^{-1} \mathrm{Cu} 4$ administered to Ç1 with $36.67 \%$. In the second year, the lowest harvest index was obtained from the parcel without copper applied to Ç1 with 38.26\%. Eren and Mert (2016) investigated the effect of increasing $\mathrm{Cu}$ applications on the growth and development of plants and found that the lowest plant dry weight of the plants was $2.28 \mathrm{~g} \mathrm{plant}^{-1}$ and $800 \mathrm{mg} \mathrm{Cu} \mathrm{kg}^{-1}$ application and control application.

As it can be seen in Table 5, zinc ( $\mathrm{Zn})$ and $\mathrm{C}$ x $\mathrm{Zn}$ dose interactions on the average harvest index were found to be statistically insignificant and significant in the second year. According to the results obtained from the experiment, the highest harvest index was obtained from the dose of $5.0 \mathrm{mg} \mathrm{kg}^{-1} \mathrm{Zn3}$ applied to Ç2 (Yakutiye-98) with $42.21 \%$. The lowest value was obtained from control (0 dose) application of Ç1 (Göynük-98) with $37.66 \%$ (Table 5). In the study, it was observed that increasing the dose of Çx $\mathrm{Zn}$ increased the harvest index up to a certain point. Taban and Alpaslan (1996) from the soil to the corn plant; in a similar study by applying 0, 2.5, 5.0 and 10.0 $\mathrm{mg} \mathrm{Zn} \mathrm{kg}{ }^{-1}$, the highest increase in dry weight (67.3\% increase) was obtained from the dose of $5.0 \mathrm{mg} \mathrm{Zn} \mathrm{kg}^{-1}$ applied to flowerpot-1 with $14.96 \mathrm{~g}$.

According to the results, the effect of cultivars $\mathrm{x} \mathrm{Cu} \times \mathrm{Zn}$ interactions on the harvest index was statistically insignificant in the first year and was significant in the second year. The average harvest index values were $34.51-48.03 \%$ in 2015 and $34.85-46.56 \%$ in 2016 (Table 5). In the second year, the highest harvest index was obtained from interaction of doses of $400 \mathrm{mg} \mathrm{Cu} \mathrm{kg}^{-1} \mathrm{Cu} 3 \times 5.0 \mathrm{mg} \mathrm{Zn} \mathrm{kg}{ }^{-1} \mathrm{Zn} 3$ applied to Yakutiye98 cultivar with $46.56 \%$ ( $\mathrm{Z2} \times \mathrm{Cu} 3 \times \mathrm{Zn} 3)$. The lowest value of $34.85 \%$ Göynük-98 variety was obtained from the application of $800 \mathrm{mg} \mathrm{kg}^{-1} \mathrm{Cu} 4 \times \mathrm{Zn} 1$ control (0 dose) (Table 5).

\section{Grain yield in the plant (g/plant)}

On the average seed yield in bean plant of different phosphorus and zinc doses in 2015 and 2016 research years; cultivar, copper, zinc, cultivar x copper, cultivar x zinc, copper $\mathrm{x}$ zinc and cultivar $\mathrm{x}$ copper $\mathrm{x}$ zinc interactions were found to be statistically significant (Table 6). Average seed yields in per plant obtained at the end of the experiment were measured as $23.49 \mathrm{~g} \mathrm{plant}^{-1}$ in the first year and $18.72 \mathrm{~g} \mathrm{plant}^{-1}$ in the second year.

According to the results, average seed yield of Göynük-98 bean cultivar was 19.35-16.87 g plant $^{-1}$ over the years, while it was 27.63-20.58 g plant $^{-1}$ in Yakutiye-98 cultivar. Düzdemir and Akdağ (2001) in their study; reported that the mean seed yield in the plant was between 10.20-27.40 $\mathrm{g} \mathrm{plant}^{-1}$. In the study of by Bildirici and Baran (2018) in under the ecological conditions of Van-Gevaș, the seed yields of Akman-98 and Göynük-98 varieties were determined as 9.82-13.44 $\mathrm{g} \mathrm{plant}^{-1}$, respectively. Seed 
yield in beans shows dependence on other genetic-based variations, especially earliness in different environmental conditions.

Table 6. Groups and averages of grain yield in bean varieties ( $g$ /plant)*

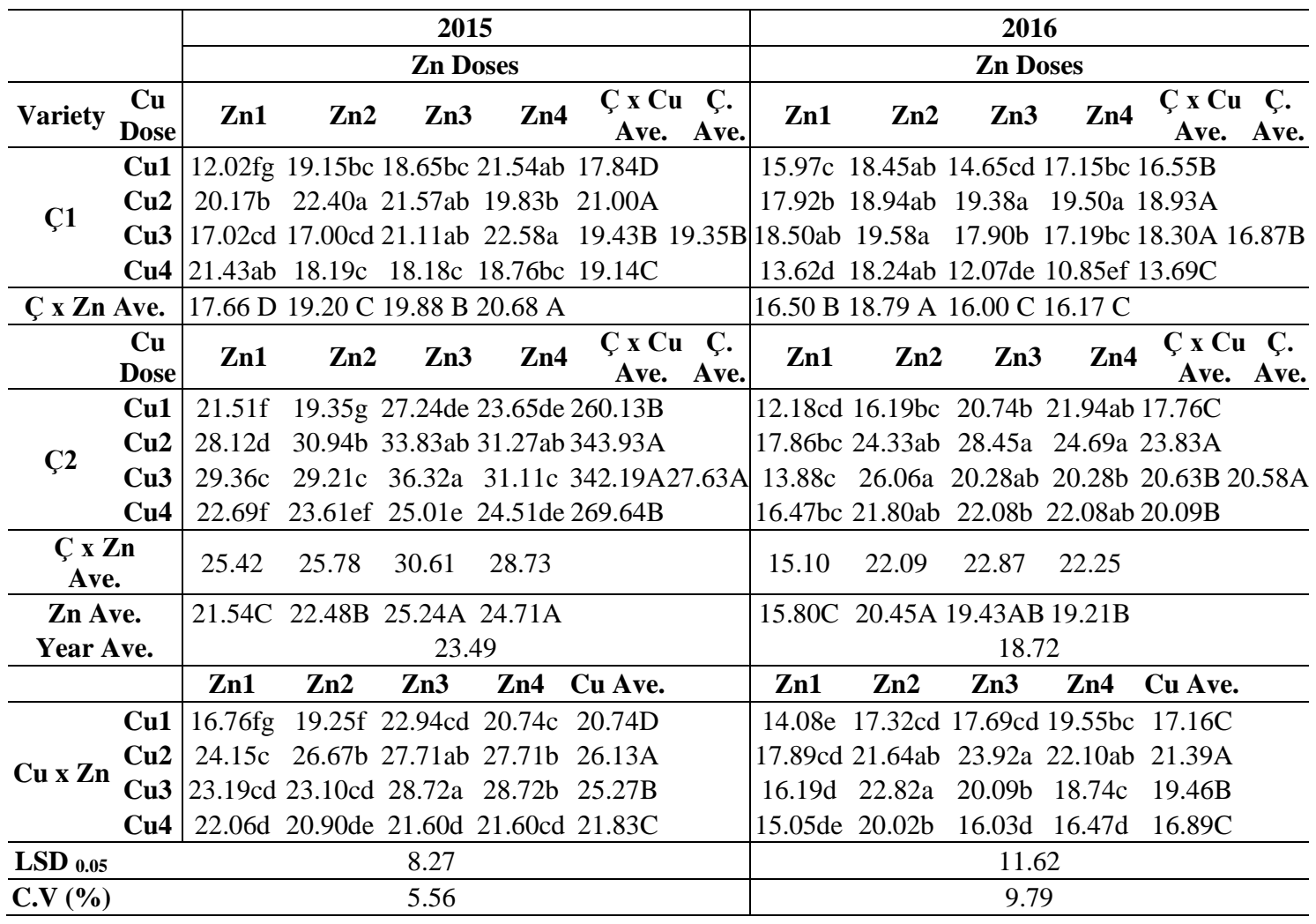

*The difference between the averages indicated by the same letters is not significant at $5 \%$ level. $\mathrm{Cu}$ : Copper Dose, Zn: Zinc Dose, Ç1: Göynük-98, Ç2: Yakutiye-98, Avg.: Average, ÇxCu: Variety x Copper Dose Interaction, Ç x Zn: Variety x Zinc Dose Interaction, $\mathrm{Cu}$ x Zn: Copper x Zinc Dose Interaction

The effects of copper fertilizer on average seed yield in the plant of beans were found to be statistically significant. The highest seed yield was obtained from the doses of $31.27-23.83 \mathrm{~g}$ plant ${ }^{-1}$ and $200 \mathrm{mg} \mathrm{kg}^{-1} \mathrm{Cu} 2$ in Yakutiye-98 cultivars in both years of the experiment. The lowest value for years 17.84-13.69 $\mathrm{g} \mathrm{plant}^{-1}$ and 0 fertilizer dose of copper and copper $\left(800 \mathrm{mg} \mathrm{kg}^{-1} \mathrm{Cu} 4\right)$ dose was determined in the parcels applied (Table 6 ). As seen in Table 6, the effect of zinc doses on average seed yields of bean cultivars was found to be significant. Average highest seed yields obtained in the experiment over the years for Yakutiye-98 bean cultivar 30.61-22.87 $\mathrm{g} \mathrm{plant}^{-1}$ and $5.0 \mathrm{mg} \mathrm{Zn} \mathrm{kg}{ }^{-1}$ $\mathrm{Zn} 3$ dose was obtained from the application. The lowest yield values (25.42-15.10 g plant $^{-1}$ ) in 0 zinc dose ( $\left.\mathrm{Zn} 1\right)$ was measured in Göynük-98 bean cultivar.

The effect of copper and zinc doses on the average seed yield of beans was significant $(\mathrm{p}<0.01)$. The highest average seed yield in both years of the study was obtained from 28.72-23.92 $\mathrm{g} \mathrm{plant}^{-1}, 200-400 \mathrm{mg} \mathrm{kg}^{-1}$ copper and $5.0 \mathrm{mg} \mathrm{kg}^{-1} \mathrm{Zn} 3$ zinc, respectively. The lowest yield value in two years 16.76-14.08 $\mathrm{g} \mathrm{plant}^{-1}$, respectively with 0 copper and zinc fertilizer dose was obtained from parcels (Table 6). The effect of copper and zinc fertilizer doses on average seed yield of bean cultivars was found to be statistically significant in both years. The highest average seed yield was obtained from 
Yakutiye-98 cultivar in 36.32-28.45 $\mathrm{g} \mathrm{plant}^{-1}$ and $400 \mathrm{mg} \mathrm{kg}^{-1}$ Copper (Cu3) x $5.0 \mathrm{mg}$ $\mathrm{kg}^{-1}$ Zinc (Zn3) application in two years. Low values 12.01-10.85 $\mathrm{g}^{\text {plant }}{ }^{-1}$ were obtained from Ç1 (Göynük-98) variety, in the cases of 0 dose and $800 \mathrm{mg} \mathrm{kg}^{-1}$ copperzinc dose ( $\mathrm{Cu} 4 \times \mathrm{Zn} 4)$ applications (Table 6).

\section{Crude protein content (\%)}

As a result of the research, the interactions of the varieties, varieties $x$ zinc, varieties $\mathrm{x}$ copper doses and copper $\mathrm{x}$ zinc doses were found to be statistically significant on the crude protein content of the grains obtained. Protein ratio by years are as follows: while Göynük-98 variety was obtained with $21.93-22.01 \%, 22.06-21.45 \%$ protein ratios were obtained from Yakutiye-98 variety (Table 7).

Table 7. Groups and averages of crude protein ratios in bean varieties $(\%) *$

\begin{tabular}{|c|c|c|c|c|c|c|c|c|c|c|c|c|}
\hline \multirow{3}{*}{ Variety } & \multirow[b]{3}{*}{$\begin{array}{c}\mathrm{Cu} \\
\text { Doses }\end{array}$} & \multicolumn{6}{|c|}{2015} & \multicolumn{5}{|c|}{2016} \\
\hline & & \multicolumn{6}{|c|}{ Zn Doses } & \multicolumn{5}{|c|}{ Zn Doses } \\
\hline & & Zn1 & $\mathrm{Zn2}$ & Zn3 & Zn4 & $\begin{array}{l}\text { Ç x Cu. } \\
\text { Ave. }\end{array}$ & $\begin{array}{c}\text { Ç. } \\
\text { Ave. }\end{array}$ & Zn1 & Zn2 & Zn3 & Zn4 & $\begin{array}{c}\text { Ç x Cu. Ç. } \\
\text { Ave. Ave. }\end{array}$ \\
\hline \multirow{4}{*}{ Ç1 } & Cu1 & 19.74 & 22.89 & 22.94 & 20.43 & 21.50 & \multirow{4}{*}{21.93} & 20.75 & 22.87 & 22.56 & 20.41 & 21.65 \\
\hline & $\mathrm{Cu} 2$ & 21.29 & 22.48 & 24.16 & 20.92 & 22.21 & & 22.66 & 22.45 & 23.35 & 21.05 & 22.38 \\
\hline & $\mathrm{Cu} 3$ & 20.36 & 23.55 & 23.06 & 22.75 & 22.43 & & 20.71 & 23.52 & 22.61 & 22.74 & $22.01 \mathrm{~A}$ \\
\hline & $\mathrm{Cu} 4$ & 20.50 & 21.83 & 22.82 & 21.23 & 21.60 & & 20.72 & 21.86 & 22.44 & 21.47 & 21.62 \\
\hline \multicolumn{2}{|c|}{ ÇxZn Ave. } & $20.47 \mathrm{D}$ & $22.69 \mathrm{~B}$ & \multicolumn{4}{|c|}{$23.25 \mathrm{~A} 21.33 \mathrm{C}$} & $21.21 \mathrm{~B}$ & \multicolumn{4}{|c|}{ 22.68A 22.74A 21.42B } \\
\hline & $\begin{array}{c}\mathrm{Cu} \\
\text { Doses }\end{array}$ & Zn1 & $\mathrm{Zn} 2$ & Zn3 & Zn4 & $\begin{array}{l}\text { Ç x Cu. } \\
\text { Ave. }\end{array}$ & $\begin{array}{l}\text { C.. } \\
\text { Ave. }\end{array}$ & Zn1 & Zn2 & Zn3 & Zn4 & $\begin{array}{c}\text { Ç x Cu. Ç. } \\
\text { Ave. Ave. }\end{array}$ \\
\hline \multirow{4}{*}{ Ç2 } & Cu1 & 21.99 & 22.88 & 22.62 & 21.15 & 22.16 & \multirow{4}{*}{22.06} & 20.99 & 22.04 & 22.25 & 22.03 & 21.83 \\
\hline & $\mathrm{Cu} 2$ & 21.81 & 22.68 & 22.14 & 22.43 & 22.27 & & 21.76 & 21.93 & 21.76 & 22.21 & 21.92 \\
\hline & $\mathrm{Cu} 3$ & 20.75 & 21.64 & 22.79 & 23.67 & 22.21 & & 20.63 & 21.64 & 21.61 & 21.37 & $21.3121 .45 \mathrm{~B}$ \\
\hline & $\mathrm{Cu} 4$ & 20.41 & 21.26 & 21.93 & 22.84 & 21.61 & & 20.40 & 20.37 & 20.81 & 21.43 & 20.75 \\
\hline \multicolumn{2}{|c|}{ ÇxZn Ave. } & \multicolumn{6}{|c|}{$21.24 \mathrm{~B} 22.12 \mathrm{~A} 22.37 \mathrm{~A} 22.52 \mathrm{~A}$} & \multicolumn{5}{|c|}{$20.95 \mathrm{~B} 21.50 \mathrm{~A} 21.61 \mathrm{~A} 21.76 \mathrm{~A}$} \\
\hline \multirow{2}{*}{\multicolumn{2}{|c|}{$\begin{array}{l}\text { Zn Ave. } \\
\text { Yl Ave. }\end{array}$}} & \multicolumn{6}{|c|}{$\begin{array}{c}20.86 \mathrm{C} 22.40 \mathrm{AB} 22.81 \mathrm{~A} 21.93 \mathrm{~B} \\
22.00\end{array}$} & \multicolumn{5}{|c|}{$\begin{array}{c}21.08 \mathrm{C} 22.09 \mathrm{AB} 22.17 \mathrm{~A} 21.59 \mathrm{BC} \\
21.73\end{array}$} \\
\hline & & Zn1 & Zn2 & Zn3 & Zn4 & Cu Ave. & & Zn1 & Zn2 & Zn3 & Zn4 & Cu Ave. \\
\hline \multirow{4}{*}{$\mathrm{Cu} \times \mathrm{Zn}$} & Cu1 & $20.87 \mathrm{bc}$ & $22.89 \mathrm{ab}$ & $22.78 \mathrm{ab} 2$ & $20.79 \mathrm{bc}$ & $21.83 \mathrm{AB}$ & & 20.87 & 22.46 & 22.41 & 21.22 & $21.74 \mathrm{AB}$ \\
\hline & $\mathrm{Cu} 2$ & $21.55 \mathrm{~b}$ & $22.58 \mathrm{ab}$ & $23.15 \mathrm{a}$ & $21.68 b$ & $22.24 \mathrm{~A}$ & & 22.21 & 22.19 & 22.56 & 21.63 & $22.15 \mathrm{~A}$ \\
\hline & $\mathrm{Cu3}$ & $20.56 \mathrm{bc}$ & $22.60 \mathrm{ab}$ & $22.93 \mathrm{ab}$ & $23.21 \mathrm{a}$ & $22.32 \mathrm{~A}$ & & 20.67 & 22.58 & 22.11 & 22.06 & $21.85 \mathrm{~A}$ \\
\hline & $\mathrm{Cu} 4$ & $20.46 \mathrm{bc}$ & $21.55 b$ & $22.38 \mathrm{ab} 2$ & $22.04 \mathrm{ab}$ & $21.60 \mathrm{~B}$ & & 20.56 & 21.12 & 21.63 & 21.45 & $21.19 \mathrm{~B}$ \\
\hline LSD $_{0.05}$ & & \multicolumn{6}{|c|}{0.51} & \multicolumn{5}{|c|}{0.54} \\
\hline C.V (\%) & & \multicolumn{6}{|c|}{4.02} & \multicolumn{5}{|c|}{4.34} \\
\hline
\end{tabular}

*The difference between the averages indicated by the same letters is not significant at $5 \%$ level. $\mathrm{Cu}$ : Copper Dose, Zn: Zinc Dose, Ç1: Göynük-98, Ç2: Yakutiye-98, Avg.: Average, ÇxCu: Variety x Copper Dose Interaction, Ç x Zn: Variety x Zinc Dose Interaction, $\mathrm{Cu}$ x Zn: Copper x Zinc Dose Interaction

The effect of different zinc doses on protein ratios in beans was found to be statistically significant in both years. The highest crude protein content by years with $5.0 \mathrm{mg} \mathrm{Zn} \mathrm{kg}{ }^{-1}$ was obtained from Göynük-98 bean cultivar with $23.25-22.74 \%$, the lowest values were obtained from 0 dose application of 20.47-20.95\%.

As shown in Table 7, the effect of copper doses on average crude protein ratios in beans was significant in 2015-16 ( $\mathrm{p}<0.05)$. The highest crude protein content was obtained from 200-400 mg kg-1 copper applications with $22.15-22.32 \%$. The lowest value was found to be $800 \mathrm{mg} \mathrm{Cu} \mathrm{kg}^{-1}$ copper $(\mathrm{Cu} 4)$ with $21.19-21.60 \%$ (Table 7). 


\section{Discussion}

In addition, plant height values were lower in both cultivars in the second year than in the first year. According to the first year of the experiment, due to the high average temperature and the lack of moisture due to the decrease in the time from the output to ripening caused the plant height values to decrease. It is thought that this difference is caused by climate in terms of plant height values between years (Elkoca and Kantar, 2004). It is thought that this difference between the years is due to the effect of climate factors as well as the usefulness of the applied copper. Çopur and Sar1 (2012) in the study of the effect of $\mathrm{CuSO}_{4} .5 \mathrm{H}_{2} \mathrm{O}$ on the growth of cucumber seedlings concluded that applications are significant in terms of seedling length. Seedling height of $9.53 \mathrm{~cm}$ of the highest seedlings with copper sulfate $4000+4000 \mathrm{mg} / 1$ were detected in the application. Zengin and Munzuroğlu (2004) investigated the effects of mercury, copper, cadmium and lead on the amount of growth hormone cytokine in bean seedlings. In their study, control seedlings and seedlings grown in $0.1,0.2$ and $0.3 \mathrm{mM} \mathrm{CuCl} 2$ solutions were measured the cytokine content of $1.83 \times 10-7,4.42 \times 10-7,3.77 \times 10-7$, $3.66 \times 10-7$ and $3.55 \times 10-7 \mathrm{M}$, respectively. They stated that growth is supported up to a point, increasing the dose of copper decreases the cytokinin level of the seedlings and this situation occurs due to increase in copper concentration. These results are consistent with our findings.

Yağmur and Aydın (2013) applied 10, 20 and $30 \mathrm{mg} \mathrm{Zn} \mathrm{kg-1} \mathrm{(ZnSO4.7H2O)} \mathrm{in} \mathrm{the}$ soil and in addition $0.1 \%, 0.2 \%$ and $0.3 \% \mathrm{ZnSO} 4.7 \mathrm{H} 2 \mathrm{O}$ solution to the leaves in lettuce cultivation. The highest plant height $(22.25 \mathrm{~cm}$ and $21.10 \mathrm{~cm})$ was obtained from applications of $20 \mathrm{mg} \mathrm{kg}-1$ zinc to the soil and $0.2 \%$ zinc to the leaves. The results obtained support our study.

Elkoca and Kantar (2004), in a similar study conducted by the number of pods between 3.5-4.2 on this variety showed a wide variation according to the variety and lines. Sönmez et al. (2006b) applied 1000 and $2000 \mathrm{mg} \mathrm{Cu} \mathrm{kg}^{-1}$ yield in tomatoes grown in the greenhouse yield, fruit number, dry root weight and plant height were reported to decrease with the amount of $\mathrm{Cu}$ in the soil. This study supports our findings. In a similar study Yağmur and Aydın (2013) applied $\mathrm{Zn}$ in the form of $0.1 \%, 0.2 \%$ and $0.3 \%$ $\mathrm{ZnSO}_{4} .7 \mathrm{H}_{2} \mathrm{O}$ solution from the leaf in addition to 10,20 and $30 \mathrm{mg} \mathrm{Zn} \mathrm{kg}{ }^{-1}$ $\left(\mathrm{ZnSO}_{4} .7 \mathrm{H}_{2} \mathrm{O}\right)$ doses. As a result of the research, they were obtained the highest plant height $(22.25 \mathrm{~cm}$ and $21.10 \mathrm{~cm})$ by applying $20 \mathrm{mg} \mathrm{kg}^{-1}$ zinc to the soil and $0.2 \%$ Zinc dose to the leaf. The results obtained from these studies are in parallel with the findings of our research.

It is thought that this difference in average number of branches over the years is due to the differences in the amount of humidity and temperature in the greenhouse as well as genetic factors (Elkoca and Kantar, 2004). Babagil et al. (2011) stated that they measured the maximum number of branches in 3.1 beans- 1 and Yakutiye-98 cultivars in their study with 6 bean cultivars under Erzurum conditions. Kumar et al. (1993) reported that zinc doses applied to the soil between 0 and $5 \mathrm{~kg} \mathrm{da}^{-1}$ increase the yield and decrease at the next doses. Similar results have been obtained in many studies (Azad et al., 1993; Yağmur and Aydın, 2013). Unlike nitrogenous fertilizers, the effect of micro nutrients on the number of branches depends on the environment and genetic structure. In the study, increasing dose of $\mathrm{Cu} \times \mathrm{Zn}$ increased the number of pods per plant up to a certain point. Wang et al. (2016) in a similar study conducted in China on Indian beans; reported that $\mathrm{Cu}$ and $\mathrm{Zn}$ interactions applied at low concentrations in the soil caused a slight increase in the growth of the plant, whereas high concentrations 
showed a significant decrease in plants height and biomass. We can assume that the interaction of $\mathrm{Cu}$ and $\mathrm{Zn}$ is clear. $\mathrm{Zn}, \mathrm{Cd}$ and $\mathrm{Cu}$ interactions related to the similar results have been reported about the interactions (Chizzola and Mitteregger, 2005; Chaoui et al., 2017).

Gangwar and Singh (1986), in their studies of zinc fertilizer increases the rate of harvest index rate has been reported that the maximum rate is taken from the applied foliar fertilizer. Azad et al. (1993) reported that zinc fertilizers increased the harvest index rate up to a certain dose and then decreased. In this study, it was observed that zinc fertilizer increased the harvest index rate up to 2.5 and $5.0 \mathrm{mg} \mathrm{Zn} \mathrm{kg}{ }^{-1}$ and then started to decrease. MacFarlane and Burchett (2002), in their study applied an increasing doses from $100 \mu \mathrm{g} \mathrm{Cu} \mathrm{g}^{-1}$ to $400 \mu \mathrm{g} \mathrm{Cu} \mathrm{g}^{-1}$ reported a reduction in total plant biomass and a decline in root growth. Therefore, similar results were obtained in this study as in many fertilization studies (Pholsen and Sormsungnoen, 2005; Barros et al., 2007). According to some other studies, it has been reported that the green parts and grain contents of wheat plant increase with $\mathrm{Zn}$ application and this increase varies according to varieties (Helaloğlu et al., 1997). Many of these studies support our findings.

It is known that there is an antagonistic effect between $\mathrm{Cu}$ and $\mathrm{Zn}$ ions (Aktaş, 1991; Chizzola and Mitteregger, 2005). Wang et al. (2016) stated that $\mathrm{Cu}$ and $\mathrm{Zn}$ interactions applied at low concentrations in the soil caused a slight increase in the growth of the plant, whereas a significant decrease in plant height and biomass was observed in high concentrations. The most important factor in determining fate of crop production is undoubtedly the growing conditions and climate factors. It is thought that this difference between years is mainly due to the fact that the average temperature and distribution in the first year $\left(21.3{ }^{\circ} \mathrm{C}\right)$ is higher compared to the second year $\left(17.90^{\circ} \mathrm{C}\right)$. In addition, the bean is very sensitive to the water balance in the soil during the flowering period. It has been reported that fluctuations in this period cause $20 \%$ yield losses in grain yield. In the first year of the research, the average temperature has been identified to be higher than the second year, especially during the flowering and pollination periods (Elkoca and Kantar, 2004). Seed yield in bean plants shows dependence on earliness of different environmental conditions in genetic variations. In the study, it was observed that the average seed yield of varieties increased up to $200 \mathrm{mg} \mathrm{kg}^{-1}$ copper dose in parallel with the increasing copper doses, and it caused decreases in seed yield in subsequent doses (Wang et al., 2016). Sönmez et al. (2006b) 1000 and $2000 \mathrm{mg} \mathrm{Cu} \mathrm{kg}{ }^{-1}$ applied to the soil in greenhouse grown tomatoes; reported that yield, fruit number, dry root weight and plant height decreased with high $\mathrm{Cu}$ doses such as. This study supports our findings. It is estimated that the difference between the first and second year zinc doses of the study is due to the fact that copper inhibits the zinc uptake more than the second year.

In the first year, it is estimated that fertilizers are used more beneficially due to the favorable conditions of the average temperature and climate (Taban et al., 1997; Toğay and Anlarsal, 2008). In studies where copper and zinc fertilizer are used together, it is known that copper $\mathrm{x}$ zinc increases the efficiency of use, decreases soil $\mathrm{pH}$, increases total $\mathrm{N}$ and $\mathrm{P}$ intake and has a positive effect on yield and quality (Sönmez et al., 2006a). In this study, it has been found that increasing doses of $\mathrm{C} \times \mathrm{Cu} \times \mathrm{Zn}$ increases the seed yield up to a certain point (Wang et al., 2016). Sonmez et al. (2006a) found that the effect of $\mathrm{Cu}$ applications on soil, which $\mathrm{Zn}$ contents was increased by $5 \%$ was significant. This study in bean is in agreement with the results of many researchers. 
In many studies, it has been determined that the protein content of bean grains varies between $17.40 \%$ and $28.00 \%$ according to the varieties and applications. It was stated that bacterial applications, especially nitrogen fertilization, increased this rate (Tajini et al., 2012). The effect of zinc fertilizer on crude protein content was found to be important depending on environmental and genotypic factors. Similar results have been obtained in other studies conducted on legume plants (Toğay and Anlarsal, 2008). Zinc is an active element in biochemical processes as well as has a biological interaction. When zinc $\left(\mathrm{Zn}^{++}\right)$is used together with copper $\left(\mathrm{Cu}^{++}\right)$, an increase in uptake occurs by plants (Sönmez et al., 2006a; Wang et al., 2016). According to some other studies; Leaf and soil zinc sulphate applications to watermelon, grapes, wheat, lentils, spinach have been found to have a positive effect on quality components yield, yield components of different crop plants, vegetative growth and development (Kaya et al., 20018).

\section{Conclusion}

In this study carried out as a greenhouse experiment in Van-Gevaş ecological conditions, the effect of different copper-zinc dose and applications and interactions on the yield and yield characteristics of dry bean cultivars grown in soilless systems were investigated. Although these factors have changed over the years, they have provided important information in terms of yield and yield components. The use of zinc at increasing copper doses and the decrease in efficacy and it has been seen decline in yield and quality parameters too. Soil analysis should be done before sowing in culture plants, especially legumes, in our province where zinc deficiency is seen too much. Based on these results, in case of deficiency, copper fertilization between 2.5-5.0 mg Zn $\mathrm{kg}^{-1}$ zinc and 200-400 mg Cu kg${ }^{-1}$ can be performed. It is known that copper zinc increases usage efficiency, decreases soil $\mathrm{pH}$, increases total $\mathrm{N}$ and intake $\mathrm{P}$ contents, and has a positive effect on yield and quality. However, it should not be ignored that it may have toxic effects in overuse. In general, the interaction of copper-zinc concentrations examined did not reach the degree of toxic effect in the plant.

As a result, co-administration of copper-zinc interactions, $400 \mathrm{mg} \mathrm{kg}^{-1} \mathrm{Cu}$ and $5.0 \mathrm{mg} \mathrm{kg}^{-1} \mathrm{Zn}$ doses resulted in an increase in yield and yield parameters in bean compared to the separate administration of these doses and was found to be statistically significant at $1 \%$ level. It is thought that this study will contribute to the new studies to reduce the yield and quality losses that may occur due to $\mathrm{Zn}$ deficiency, $\mathrm{Cu}$ excess or interactions in agricultural soils.

\section{REFERENCES}

[1] Aktaş, M. (1991): Plant Nutrition and Soil Fertility. - AÜ Faculty of Agriculture Publications: 1202, Textbook: 347, Ankara, 345 p.

[2] Azad, A. S., Manchada, J. S., Gill, A. S., Bains, S. S. (1993): Effect of Zinc Application on Glrain Yield, Yield Components and Nutrient Content of Lentil. - Lens Newsletter 20(2): 3033.

[3] Babagil, G., Tozlu, E., Dizikisa, T. (2011): Determination of Yield and Yield Components of Some Haricot Bean (Phaseolus vulgaris L.) Genotypes Grown in Erzincan and Hinis Ecological Conditions. - Atatürk University Journal of the Faculty of Agr. Sci 42(1): 11-17. 
[4] Barros, I., Gaiser, T., Lange, F. M., Römheld, V. (2007): Mineral nutrition and water use patterns of a maize/cowpea intercrop on a highly acidic soil of the tropic semiarid. - Field Crops Research 101: 26-36.

[5] Bildirici, N., Demir, C., Demir, H. (2016): Effects of Heavy Metals on Bean Plant. - Int. Environmental Application \& Sci. 11(3): 267-269.

[6] Bildirici, N., Baran, İ. (2018): Determine of Yield and Yield Components of Some Dry Bean (Phaseolus vulgaris L.) Varieties and One Local Ahlat Population in The VanGevaş Ecological Conditions. - International Journal of Research In Agricultural and Food Sciences 10(1): 2311-2476.

[7] Bolat, İ., Kara, Ö. (2017): Plant Nutrients: Sources, Functions, Deficiencies and Excesses. - Bartin Orman Fakültesi Dergisi 19(1): 218-228. (in Turkish).

[8] Buttaro, D., Serio, F., Santamaria, P. (2012): Soilless greenhouse production of table grape under Mediterranean conditions. - Journal of Food, Agriculture \& Environment 10(2): 641645.

[9] Chaoui, A., Ghorbal, M. H., Ferjani, E. (2017): Effects of cadmium-zinc interactions on hydroponically grown bean (Phaseolus vulgaris L.). - Plant Science 126(1997): 21-28.

[10] Chizzola, R., Mitteregger, U. S. (2005): Cadmium and zinc interactions in trace element accumulation in chamomile. - J. Plant Nutr 28(8): 1383-1396.

[11] Çopur, H., Sarı, N. (2012): The effects of paclobutrazole and copper sulphate applications on seedling growth in greenhouse cucumber seedlings. - J. Agric. Fac. ÇÜ 27(1): 1-12.

[12] Dağhan, H., Öztürk, M. (2015): Soil pollution in Turkey and remediation methods. - In: Hakeem, K. R., Sabir, M., Ozturk, M., Mermut, A. (eds.) Soil Remediation and Plants: Prospects and Challenges. September 2015, Academic Press, Elsevier, New York, pp. 287312.

[13] Di Lorenzo, R., Pisciotta, A., Santamaria, P., Scariot, V. (2013): From soil to soilless in horticulture: Quality and typicity. - Italian Journal of Agronomy 8(4): 255-260.

[14] Düzdemir, O., Akdağ, C. (2001): Türkiye Kuru Fasulye (Phaseolus vulgaris L.) Gen Kaynaklarının Karakterizasyonu: 2. Verim ve Diğer Bazı Özellikleri. - GOÜ Ziraat Fakültesi Dergisi 18(1): 101-105.

[15] Düzgüneş, O., Kesici, T., Koyuncu, O., Gürbüz, F. (1987): Research and Experimental Methods. - AÜ Faculty of Agriculture Publications: 1021, Textbook: 295, S.381.

[16] Elkoca, E., Kantar, F. (2003): Determination of early and high yield dry bean (Phaseolus vulgaris L.) genotypes suitable for erzurum ecological conditions. - Atatürk Univ. Journal of Agriculture Sci 35(3-4): 137-142.

[17] Eren, A., Mert, M. (2016): Investigation of table grape cultivation in soilless culture system. - Turkey Agricultural Research Journal 4(1): 50-58.

[18] FAO. (2017): Agricultural Statistics. - http://faostat3.fao.org/browse/Q/QC/E (13.05.2019).

[19] Gangwar, K. S., Singh, N. P. (1986): Effect of Zinc Application on Yield and Quality of Lentil (Lens culinaris Medic.). - Legume Research 11(1): 11-14.

[20] Gül, A. (2008): Soilless Agriculture. - Hasad Publishing, İstanbul, 135p.

[21] Helaloğlu, C., Torun, B., Tolay, İ., Çakmak, İ. (1997): Reactions of various wheat genotypes to zinc fertilization in Harran plain irrigated conditions and selection of zinc deficiency resistant genotypes. - I. National Zinc Congress, May 12-16, 1997, Eskisehir, Journal of Bartin Faculty of Forestry 19(1): 218-228.

[22] Kacar, B., Katkat, V. (2006): Plant nutrition. - Nobel Publication, Number: 849.

[23] Kaplan, M. (1999): Accumulation of Copper in Soils and Leaves of Tomato Plants in Greenhouses in Turkey. - Journal of Plant Nutrition 22(2): 237-244.

[24] Karaca, A., Turgay, O. C. (2012): Soil pollution. - Journal of Soil Science and Plant Nutrition 1(1): 13-19.

[25] Kaya, Y., Zengin, M., Y1lmaz, F. G., Gezgin, S. (2018): Effects of gibberellic acid and zinc applications on yield and yield components of lettuce. - SÜ J Agr Food Sci 32(3): 373-380. 
[26] Kumar, P., Agarwal, J. P., Chandra, S. (1993): Effect of inoculation, nitrogen and phosphorus fertilization on growth and yield of lentil. - Lens newsletter 20(1): 57-59.

[27] Lindsay, W. L., Norvell, W. A. (1978): Development of a DTPA soil test for zinc, iron, manganese, and copper. - Soil Science Society of America Journal 42: 421-428.

[28] MacFarlane, G. R., Burchett, M. D. (2002): Toxicity, growth and accumulation relationships of copper, lead and zinc in grey mangrove Avicennia marina (Forsk.) Vierh. - Marine Environmental Research 54(1): 65-84.

[29] Marschner, H. (1997): Minereal Nutrition of Higher Plants. - Institute of Plant Nutrition, University of Hohenheim. Academic Press, Inc., Sandiego, CA 9210, Germany, 889p.

[30] McCauley, A., Jones, C., Jacobsen, J. (2009): Nutrient Management. - Nutrient management module 9 Montana State University Extension Service 4449-9: 1-16.

[31] Öktüren Asri, F., Sönmez, S. (2007): The Effect of Heavy Metal Toxicity on Plant Metabolism. - Derim 23(2): 36-45.

[32] Pholsen, S., Sormsungnoen, N. (2005): Effects of nitrogen and potassium rates and planting distances on growth, yield and fodder quality of a forage sorghum (Sorghum bicolor L.). - Pakistan Journal of Biological Sciences 7: 1793-1800.

[33] Plaster, E. J. (1992): Soil Science and Management. $-2^{\text {nd }}$ Edition, Delmar Publishers Inc., Albany, New York, USA.

[34] Raven, J. A., Evans, M. C. W., Korb, R. E. (1999): The role of trace metals in photosynthetic electron transport in O2-evolving organisms. - Photosynth. Res. 60(2-3): 111-149.

[35] Rout, G. R., Das, P. (2003): Effect of metal toxicity on plant growth and metabolism: I. Zinc. - Agronomie 23: 3-11.

[36] Sönmez, S., Kaplan, M., Sönmez, N. K., Kaya, H. (2006a): The effect of copper applications from soil on soil $\mathrm{pH}$ and plant nutrient contents. - J. Mediterranean Agricultural Sciences 19(1): 151-158.

[37] Sönmez, S., Kaplan, M., Sönmez, N. K., Kaya, H., Uz, İ. (2006b): High level of copper application to soil and leaves reduce the growth and yield of tomato plants. - Sci. Agric. (Piracicaba, Braz.) 63(3): 213-218.

[38] Sossé, B. A., Genet, P., Dunand-Vinit, F., Toussaint, L. M., Epron, D., Badot, P. M. (2004): Effect of copper on growth in cucumber plants (Cucumis sativus) and its relationships with carbonhydrate accumulation and changes in ion contents. - Plant Science 166: 1213-1218.

[39] Şehirali, S. (1988): Yemeklik Tane Baklagiller. - AÜ Ziraat Fakültesi Yayınları 1089, Ders Kitabi: 314.

[40] Taban, S., Alpaslan, M. (1996): Effect of Zinc Fertilization on Zinc, Iron, Copper, Manganese and Chlorophyll Content of Corn Plant. - Pamukkale University, Journal of Engineering Sciences 2(1): 69-73.

[41] Taban, S., Alpaslan, M., Güneş, A., Aktaş, M., Erdal, İ., Eyüboğlu, H., Baran, İ. (1997): The effect of zinc applied in different forms on yield and biological usefulness of wheat in wheat plant. - I. National Zinc Congress, May 12-16, 1997, Eskisehir.

[42] Tajini, F., Trabelsi, M., Drevon, J. (2012): Combined Inoculation with Glomus Intraradices and Rhizobium tropici CIAT 899 Increases Phosphorus Use Efficiency for Symbiotic Nitrogen Fixation in Common Bean (Phaseolus vulgaris L.). - Saudi Journal of Biological Sciences 19: 157-163.

[43] Tangolar, S., Tangolar, S., Alkan Torun, A., Tarım, G., Ada, M. (2017): Investigation of table grape cultivation in soilless culture system. - Journal of Turkey Agricultural Research 4(2): 163-170.

[44] Togay, Y., Anlarsal, A. E. (2008): Effect of different doses of zinc and phosphorus on yield and yield components in lentil (Lens culinaris Medic.). - Yüzüncü Y1l University, Journal of Agricultural Sciences 18(1): 49-59.

[45] TUIK. (2018): Agricultural Statistics. - http://www. tuik.gov.tr/PreTablo.do?alt_id= 1001 (13.05.2019). 
[46] Wang, S., Zhao, Y., Guo, J., Zhou, L. (2016): Effects of $\mathrm{Cd}, \mathrm{Cu}$ and $\mathrm{Zn}$ on Ricinus communis L. Growth in single element or co-contaminated soils: Pot experiments. Ecological Engineering 90: 347-351.

[47] Yağmur, B., Aydın, Ş. (2013): The Effects of Zinc and Soil Applications on the Development of Lettuce (Lactuca sativa L.) and Some Mineral Substance Coverage. Anadolu, J. of AARI. 23(2): 36-43. (in Turkish with English Abstract).

[48] Yalçın, S. R., Usta, S. (1990): The effect of zinc application on the development of corn plant and zinc, iron, manganese and copper scopes. - AÜ Faculty of Agriculture Yearbook 41(1-2): 195-204.

[49] Zengin, F. K., Munzuroğlu, Ö. (2004): Effects of lead ( $\mathrm{Pb}++)$ and copper $(\mathrm{Cu}++)$ on the growth of root, shoot and leaf of bean (Phaseolus vulgaris L.) seedlings. - Gazi Universty Journal of Science 17(3): 1-10. 